\title{
FURTHER STUDIES ON THE RECOVERY OF FERTILITY IN MICE AFTER PROTRACTED STEROID- INDUCED STERILITY
}

\author{
A. LIPSCHUTZ, R. IGLESIAS AND SOCORRO SALINAS \\ Institute of Experimental Medicine, National Health Service, \\ Avenida Irarrázaval 849, Santiago, Chile
}

(Received 1st January 1963)

\begin{abstract}
Summary. Females of strain BALB were maintained sterile for 13 to 20 months by the subcutaneous implantation of pellets containing $40 \%$ of 19-nor-progesterone. The life-span of the treated animals was not shorter than that of normal breeding females. Pregnancy can still take place when the pellet is removed after having caused sterility during 395 days, i.e. till the moment when, in normal animals, $98 \%$ of the reproductive task has been fulfilled.

The females emerging from a steroid-induced sterility of 395 days behaved as to reproduction like normal aged females: litter frequency and litter size were as small as in the latter.

The sterilizing 19-nor-steroid produced ovarian tumours in a considerable percentage of animals. It is not probable that the reproductive activity after removal of the pellets was impaired by these tumours.

The experimental conditions as established by the protracted administration of the sterilizing anti-ovulatory steroid represent, supposedly, the maximum sparing of oocytes hitherto obtained. The decline of fertility not being counteracted by this sparing, it would seem that the gerontological decline of fertility is not dependent on the diminished number of oocytes available in the senile ovary.

It is not yet possible to locate the gerontological factor responsible for the decline of fertility, in the ovary, or in the hypophysis, or in any other part of the body.
\end{abstract}

\section{INTRODUGTION}

In previous work evidence was reached that there is full recovery of fertility in mice of the strain BALB when sterility induced by 19-nor-progesterone was maintained for as long as 108 to 176 days (Lipschutz \& Iglesias, 1961a). In a group of twenty-two females there was not a single animal which would have failed to produce litters when the subcutaneously implanted pellet of the sterilizing steroid was removed; the average size of these litters was the same as in normal animals.

When after the first post-sterility delivery observations were continued for as long as 8 months, fertility always remained unaltered, i.e. equal to that of 
normal animals (Lipschutz \& Iglesias, 1961b). With twenty-two normal females there were in the course of these 8 months 140 litters with 927 offspring, or 6.6 per litter. With twenty-two post-sterility females, i.e. females maintained sterile for 108 to 176 days, there were after removal of the sterilizing steroid during the same 8 months, 133 litters with 871 offspring, or 6.5 per litter.

There may sometimes be a delay in conception after removal of the sterilizing steroid as already stated by Bruce (1959). In most of our animals pregnancy began about 10 to 15 days after removal of the steroid; in some animals the delay was of 20 to 25 days. Only in one animal the delay was of somewhat more than 2 months. The young were suckled as with normal females; these young reached reproductive maturity at the same age as animals born by normal females.

Our former experiments thus gave full evidence that sterility can be maintained in mice by the continuous administration of a progestational steroid for as long as 6 months, which corresponds to half of the normal reproductive life-span; that reproductive activity is regained by all the animals when the administration of the sterilizing steroid is suspended, and that reproduction after such a protracted sterility induced by a steroid is quantitatively normal.

These results may interest from a practical point of view, i.e. when trying to apply similar results to women. However, there was in our work another aspect which we have discussed more fully in our second paper (1961b): similar experimental procedures may open hitherto unsuspected possibilities of studying quantitative and temporal conditions of reproduction in mammals. In our strain BALB, reproduction starts at an age of about 2 months but begins to decrease at about 10 to 12 months: the number of offspring per litter and later the average number of litters per month begins to diminish. Our findings with BALB coincide with those of the Mühlbock group in the same and other strains of mice (Thung, Boot \& Mühlbock, 1956; Mühlbock, 1957).

\section{What are the dynamics of this gerontological phenomenon?}

There are first the findings in unilaterally spayed females. It has been known since the classical work of Hunter (1787) on the pig that the number of offspring per litter remains normal after the removal of one ovary. This was subsequently shown to be true also in the rat (Arai, 1920), in the rabbit (Asdell, 1924; Hammond, 1925), in the opossum (Hartman, 1925), in the guinea-pig (Lipschutz \& Adamberg, 1925) and in the hamster (Greenwald, 1961, 1962). The number of young per litter was nearly equal to the normal in the rabbit even when as much as one entire ovary and about two-thirds of the second ovary were removed (Asdell, 1924; Hammond, 1925). The remaining ovary, and the remaining ovarian fragment, undergo 'hypertrophy' (Garmichael \& Marshall, 1908; Lipschutz, Wagner \& Tamm, 1922; Lipschutz, Wagner, Tamm \& Bormann, 1922; Asdell, 1924; Slonaker, 1927). This ovarian 'hypertrophy' is due to the number of ripening follicles approaching the normal (Arai, 1920; Hartman, 1925; Lipschutz, 1925, 1928; Lipschutz \& Voss, 1925b; Mandl, Zuckerman \& Patterson, 1952).

The above findings were summarized by the term of the 'law of numerical follicular constancy’ (Lipschutz \& Voss, 1924; Lipschutz, Adamberg, Tütso \& 
Veshniakov, 1926; Lipschutz, 1927; Mandl et al., 1952). The assumption was also made that the ovarian events are in quantitative obedience to an extraovarian factor (Heape, Sand, Hammond, Lipschutz).* It is what Hunter termed as early as 1787 the 'constitution' of the body: 'it seems most probable that the ovaries are from the beginning destined [by the constitution of the body] to produce a fixed number [of young], ... although circumstances may tend to diminish that number".

Hunter in the course of his experiments, made another fundamental finding: the semi-spayed animal produced eight litters and remained sterile for the last 2 years when the normal animal still produced another five litters. These latter findings of Hunter's have been fully corroborated more recently in mice (Jones \& Krohn, 1960a; Biggers, Finn \& McLaren, 1962a). Hunter was unable to give a satisfactory explanation for this phenomenon, though he was aware that the observation itself - the remaining ovary producing its total number of offspring "in a less time than would probably have been the case if both ovaries had been preserved"-was a very pertinent one.

Why does the remaining ovary cease to produce mature follicles before the normal time?

Attention was given first to local, i.e. ovarian conditions. It was thought that in the remaining ovary, which has to produce twice the number of mature ova, there is a premature depletion of oocytes. Thus, in the rabbit with subtotal ovariectomy when only a small part of the ovary is left in the body, there is in the small ovarian remnant a considerable diminution of primary follicles or oocytes (Lipschutz, 1928). However, as has been shown by Jones \& Krohn (1960b) in work with ovarian orthotopic grafts in mice, a considerable loss of oocytes takes place rapidly due most probably to ischaemia during the interval which elapses before the circulation is restored. This statement makes it very improbable that the depletion of ova in the ovarian remnant was due to the increased consumption of oocytes. The same authorities have also given evidence that there is no depletion of oocytes in the remaining ovary in the semi-spayed animal (Jones \& Krohn, 1960a). Normal mice of the strain used had their last litter at 363 days; semi-spayed mice had the last litter at 280 days, in full accordance with Hunter's classical work in pigs. However, in Jones \& Krohn's experiments on mice the number of oocytes in the remaining ovary was the same as in the normal one. All this is in favour of the assumption that the reproductive life-span is not primarily dependent on a depletion of oocytes, or on an ovarian factor, but on some extra-gonadal factor. In other words: it would seem that there is in the body of the mammal an extra-ovarian gerontological factor limiting reproduction.

We have thought that protracted steroid-induced sterility with its supposedly profound impact on the gonadotrophic function of the hypophysis and, through the intermediation of the latter, also on the ovary, might offer the opportunity to approach in some way the involved problem of the dynamics of ovarian function according to age. We thought that the first step to approach this problem would be to study the reproductive behaviour of mice maintained in

* For the literature of about 40 to 50 years ago one may refer to the papers quoted above. Modern summaries: Hammond (1952), Brambell (1956) and various authorities in Zuckerman (1962).

D* 
a steroid-induced sterility for the greater part of the reproductive life-span so as to allow for ovarian ovulatory activity only shortly before the end of the normal life-span. Will similar ovaries remaining, supposedly, at 'follicular rest' - though certainly a very relative one, but one which exceeds that which is imposed by virginity-behave differently from the normal ovary of aged animals, when the sterilizing steroid is removed?

\section{MATERIALS AND METHODS}

Pellets containing $40 \%$ of 19 -nor-progesterone were implanted subcutaneously into virgin BALB females. The weight of the pellets was of 25 to $30 \mathrm{mg}$. Absorption as calculated from the loss of weight was of 4 to $19 \mu \mathrm{g} /$ day. Indeed, in experiments of long duration these figures are not exact. Pellets were renewed 220 and 395 days after the first implantation.

The animals were, with only a few exceptions, $2 \frac{1}{2}$ to 3 months old. A normal female of the same age was kept together with the treated one in the same cage. A male was kept permanently with each of these pairs.

\section{RESULTS}

\section{Reproductive behaviour of normal females}

A total of twenty-four normal females were under observation during 23 months. The average life-span was of 532 days which was reached by two-thirds of the animals. All animals, without exception, were fertile. Fertility was sustained up to an age of about 22 months; the last litter was from an animal 655 days old. But the reproductive behaviour undergoes in the course of time two significant changes which are of especial interest for comparison with our experimental animals. The frequency of litters per animal and per month does not undergo any change till the age of about 14 months but it then deteriorates rapidly from 0.8 per animal and per month to 0.25 and 0.1 in the 18th or 19th month (Text-fig. 1, lower).

The litter size varies between one and thirteen. It begins to decline earlier than the litter frequency, apparently from the age of about 10 months (Textfig. 1, upper), i.e. 4 or 5 months before the litter frequency has started to decline. The average number of offspring in the litter declines from seven or eight at its peak, to six by the 12 th month, and to four by the 15 th or 16 th month. Litters of as many as thirteen offspring occur during the peak breeding period, declining from the age of 10 to 12 months until at an age of 17 or 18 months the largest litters had only six offspring. One may say that in our strain the age of 10 to 16 months is the 'critical period' in the reproductive behaviour of the female. Or, if one likes: the period when 'physiology' begins to overlap with 'gerontology'. The curve of decline of litter size with ageing in the present group of twenty-four animals conformed to that obtained in earlier work of ours with 220 litters and 1422 young (Lipschutz \& Iglesias, 1961b, Fig. 1 on p. 218).

The decline of fertility can be expressed also in the curve of the relation of litter size to litter order, as done by Biggers, Finn, McLaren \& Woolf (1962b). The reproductive life-span of our strain BALB is much shorter than that of 
Biggers's strain; but the respective curve is similar in both strains (Text-fig. 2; compare with Text-fig. 2 of Biggers et al., 1962b).

As will be shown especially in the present paper, there is the definite fact that the decline of litter size is not a function of the litter order but a function of
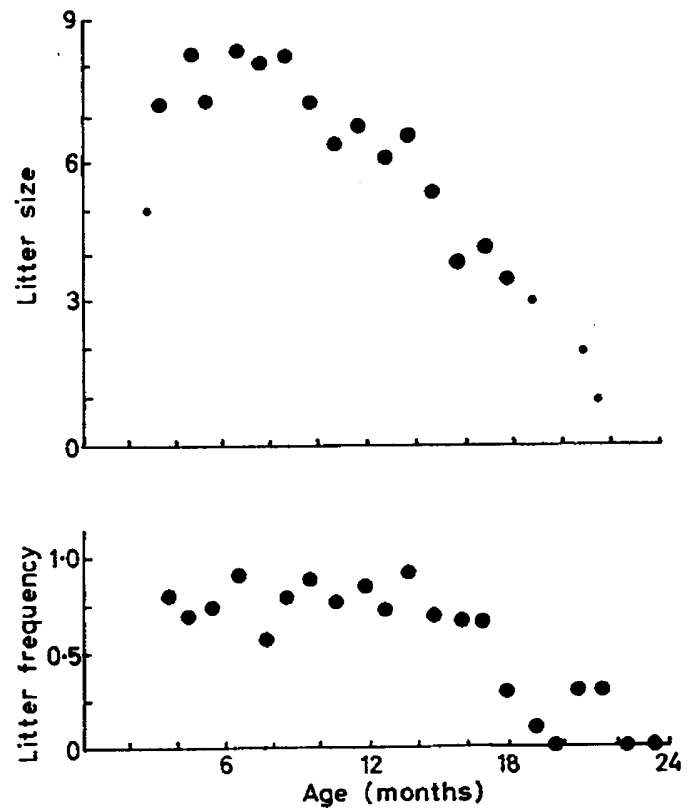

TEXT-FIG. 1. Reproduction of twenty-four females during 21 months. Total 232 litters with 1580 offspring.

Top: Average number of offspring per litter in normal females.

- Only one litter.

Bottom: Average frequency of litters per animal and month.

Frequency with which pregnancy occurs seems to be stable till the age of about 14 months when a rapid decline sets in (lower). The average number of offspring per litter begins to decline earlier than that (upper); the decline is notable already at about the 10 th month.

Text-fig. 1 is based on the following figures:

$\begin{array}{cccc}\begin{array}{c}\text { Age } \\ \text { (days) }\end{array} & \begin{array}{c}\text { No. } \\ \text { animals }\end{array} & \begin{array}{c}\text { No. } \\ \text { litters }\end{array} & \begin{array}{c}\text { No. } \\ \text { young }\end{array} \\ 91 \text { to } 120 & 15 & 12^{*} & 84 \\ 121 \text { to } 150 & 24 & 17 & 140 \\ 151 \text { to } 180 & 24 & 18 & 129 \\ 181 \text { to } 210 & 24 & 23 & 191 \\ 211 \text { to } 240 & 24 & 14 & 113 \\ 241 \text { to } 270 & 24 & 19 & 156 \\ 271 \text { to } 300 & 24 & 21 & 154 \\ 301 \text { to } 330 & 22 & 17 & 111 \\ 331 \text { to } 360 & 21 & 18 & 123 \\ 361 \text { to } 390 & 20 & 14 & 86\end{array}$

* One animal only 84 days old.

$\begin{array}{cccc}\begin{array}{c}\text { Age } \\ \text { (days) }\end{array} & \begin{array}{c}\text { No. } \\ \text { animals }\end{array} & \begin{array}{c}\text { No. } \\ \text { litters }\end{array} & \begin{array}{c}\text { No. } \\ \text { young }\end{array} \\ 391 \text { to } 420 & 20 & 18 & 119 \\ 421 \text { to } 450 & 19 & 13 & 70 \\ 451 \text { to } 480 & 17 & 11 & 43 \\ 481 \text { to } 510 & 16 & 10 & 41 \\ 511 \text { to } 540 & 15 & 4 & 14 \\ 541 \text { to } 570 & 10 & 1 & 3 \\ 571 \text { to } 600 & 5 & 0 & 0 \\ 601 \text { to } 630 & 4 & 1 & 2 \\ 631 \text { to } 660 & 4 & 1 & 1 \\ 661 \text { to } 690 & 3 & 0 & 0 \\ 691 \text { to } 720 & 3 & 0 & 0\end{array}$

age. The curve of Text-fig. 1 is the immediate or direct expression of the very relevant gerontological reality of reproduction; the curve of Text-fig. 2 is but an indirect expression of this gerontological reality.

Reproductive behaviour as a function of age can be expressed also in another 
convenient way as done in Table 1 . At the age of 400 days, $85 \%$ of the production of offspring of the group has been accomplished and at 500 days almost the whole reproductive task has been fulfilled.

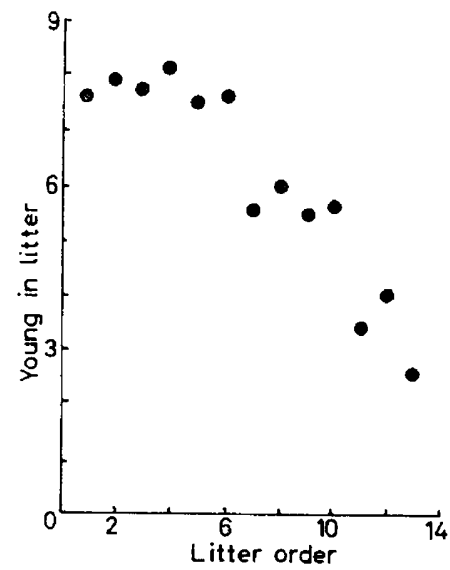

Text-FIG. 2. Average litter size related to litter 'order'. In the first to the fifth litter the average number of young per litter varies between seven and eight. From the sixth litter on the decline of litter size is very considerable. The coincidence with Text-fig. 2 of Biggers et al. (1962) working with another strain of mice is impressive.

TABLE 1

PRODUCTION OF OFFSPING BY TWENTY-FOUR NORMAL FEMALES DURING THEIR LIFE-SPAN

\begin{tabular}{r|c|c|c|c|c|c}
\hline $\begin{array}{c}\text { Age-group } \\
\text { (days) }\end{array}$ & $\begin{array}{c}\text { Animal* } \\
\text { No. }\end{array}$ & $\begin{array}{c}\text { No. } \\
\text { animals } \\
\text { with } \\
\text { litters }\end{array}$ & $\begin{array}{c}\text { No. } \\
\text { litters }\end{array}$ & $\begin{array}{c}\text { No. young } \\
\text { produced } \\
\text { by the } \\
\text { age group }\end{array}$ & $\begin{array}{c}\text { Total } \\
\text { No. young } \\
\text { hitherto } \\
\text { produced }\end{array}$ & $\begin{array}{c}\% \\
\text { of } \\
\text { total } \\
\text { production }\end{array}$ \\
\hline 84 to 400 & $24-20$ & 24 & 180 & 1342 & 1342 & 85 \\
401 to 500 & $20-16$ & 19 & 42 & 207 & 1549 & 98 \\
501 to 558 & $16-13$ & 8 & 8 & 24 & 1573 & 99 \\
628 to 655 & 4 & 1 & 2 & 3 & 1576 & 100 \\
\hline
\end{tabular}

* Alive at the beginning, and at the end, in the respective age-group.

Protracted steroid-induced sterility and the comparative life-span of normal and treated animals

Animals were maintained in steroid-induced sterility for as long as 13 to 20 months, i.e. till the age of about 16 to 23 months, so as to reach, or slightly surpass, the 'critical period' in the reproductive behaviour of the normal female as discussed above.

No animal in a group of eleven with pellets during 13 to 20 months (see details in Table 2) gave birth to a litter. Thus there is full evidence that steroid-induced sterility can be maintained during more than 20 months, up to the age of 23 months, i.e. up to the end of fertility of a normal female. 
TABLE 2

PROTRACTED STERILITY: PELLETS OF

19-NOR-PROGESTERONE PRESENT DURING 402 TO 622 DAYS

\begin{tabular}{c|c|c|c}
\hline $\begin{array}{c}\text { Animal } \\
\text { No. }\end{array}$ & $\begin{array}{c}\text { Age at } \\
\text { first } \\
\text { implantation } \\
\text { (days) }\end{array}$ & $\begin{array}{c}\text { Duration } \\
\text { of } \\
\text { treatment } \\
\text { (days) }\end{array}$ & $\begin{array}{c}\text { Age } \\
\text { at } \\
\text { death } \\
\text { (days) }\end{array}$ \\
\hline 1 & 69 & 439 & 508 \\
2 & 43 & 481 & 524 \\
3 & 79 & 459 & 538 \\
4 & 70 & 480 & 550 \\
5 & 72 & 481 & 553 \\
6 & 71 & 534 & 605 \\
7 & 72 & 537 & 608 \\
8 & 69 & 559 & 628 \\
9 & 78 & 621 & 699 \\
10 & $260^{*}$ & 402 & 693 \\
11 & $243^{*}$ & 402 & 705 \\
& & & \\
\hline
\end{tabular}

* Loss of pellets after the first implantation and transitory recuperation of fertility. Treatment (sterility) calculated only after the second implantation.

No animal gave birth to a litter. Implantation of pellets renewed at 220 and 395 days after the first one. Weight of pellets: 25 to $30 \mathrm{mg}$ (10 to 12 $\mathrm{mg}$ of 19-nor-progesterone). Absorption per day: 4 to $13 \mu \mathrm{g}$ (average 8.5 $\mathrm{\mu g}$ ). Figures of absorption not exact.

TABLE 3

GOMPARATIVE LIFE-SPAN OF NORMAL AND EXPERIMENTAL ANIMALS

\begin{tabular}{c|c|c}
\hline $\begin{array}{c}\text { Age at death } \\
\text { (days) }\end{array}$ & $\begin{array}{c}\text { No. normal } \\
\text { females }\end{array}$ & $\begin{array}{c}\text { No. females } \\
13 \text { to 20 months with } \\
\text { 19-nor-progesterone } \\
\text { (Tables 1 and 5) }\end{array}$ \\
\hline $\begin{array}{c}307 \text { to } 494 \\
508 \text { to } 599 \\
602 \text { to } 699 \\
701 \text { to } 718\end{array}$ & 11 & 0 \\
Total & 3 & 8 \\
\hline $\begin{array}{c}\text { Average life-span } \\
\text { (days) }\end{array}$ & $533 \pm 23$ & 3 \\
\hline 508 to 718 & 24 & 18 \\
\hline Total* & 16 & $597 \pm 18$ \\
\hline $\begin{array}{c}\text { Average life-span } \\
\text { (days) }\end{array}$ & 593 & 597 \\
\hline
\end{tabular}

* i.e. omitting the group of 307 to 494 days. 
Has the protracted steroid-induced sterility been harmful to our mice? There is first the question of the comparative life-span of normal animals and of those treated for 13 to 20 months with 19-nor-progesterone.

As seen from Table 3, the average life-span of eighteen experimental animals which were under the action of the steroid for 13 to 20 months, was even longer than that of normal animals. The difference is due to eight out of the twentyfour normal animals not reaching the minimum life-span of the treated animals. Is this difference due to the stress of repeated pregnancies? The number of our normal and experimental animals is certainly too small to allow a satisfactory answer to this question. But there is the fact that the eight normal animals with a shorter life-span (Table 4) delivered at the age of $8 \frac{1}{2}$ to 16 months only fortyseven young per animal, against sixty-two per animal produced in the same period of life by the group of sixteen normal animals with a longer life-span. This statement gives sufficient evidence that the life-span does not depend on, or is not shortened by, the number of offspring produced.

TABLE 4

GOMPARATIVE FERTILITY IN ANIMALS OF SHORT AND LONG LIFE-SPAN

\begin{tabular}{c|c|c|c|c|c|c}
\hline $\begin{array}{l}\text { Group } \\
\text { (days) }\end{array}$ & $\begin{array}{c}\text { Life-span } \\
\text { (days) }\end{array}$ & $\begin{array}{c}\text { No. } \\
\text { animals }\end{array}$ & $\begin{array}{c}\text { Age-group } \\
\text { (last litters, } \\
\text { range) } \\
\text { (days) }\end{array}$ & $\begin{array}{c}\text { No. } \\
\text { litters } \\
\text { (average) }\end{array}$ & $\begin{array}{c}\text { No. } \\
\text { young/litter } \\
\text { (average) }\end{array}$ & $\begin{array}{c}\text { No. } \\
\text { young/animal } \\
\text { (average) }\end{array}$ \\
\hline A & 307 to 494 & 8 & 254 to 490 & 7.4 & 6.4 & 47 \\
B & 527 to 705 & 16 & 292 to $492 *$ & 7.9 & 7.8 & 61 \\
\hline
\end{tabular}

* Litters which occurred, in $\mathrm{B}$, during the life-span of $A$.

The question of the comparative life-span of normal and treated animals can be dealt with very successfully by recourse to the following argument. As we have seen before (Table 1), at the age of 500 days $98 \%$ of the prospective offspring have already been produced. It seems then reasonable to compare the life-span of normal and treated animals at the age of more than 500 days, when comparison is practically not interfered with by the problem of the impact of pregnancies. As seen from Table 3, quantities of 19-nor-progesterone administered for as long as 13 to 20 months and sufficient to maintain the animal sterile do not shorten the life-span of the treated animals.

\section{Recuperation of fertility after protracted steroid-induced sterility, and the age factor of fertility}

In earlier work the longest duration of steroid-induced sterility was 176 days with full recuperation of fertility after removal of the pellets (Lipschutz \& Iglesias, 196Ib); all animals became pregnant when the pellets were removed.

In Table 5 new experiments are given in which 19-nor-progesterone was allowed to act for a much longer time before removal of the pellets.

The sterilizing pellets were removed after 395 days, when the animals had reached an age of 484 to 496 days. It is the age when the average litter size in normal animals is only about four, when the frequency of litters begins 
rapidly to decline (Text-fig. 1), and when $98 \%$ of the reproductive task has been fulfilled (Table 1).

Several of the aged animals died 1 month after the removal of the pellets (Table 5), reaching the average of 524 days, as did other treated animals (Table 2) and normal animals (Table 3 ). The remaining three animals surviving 616 to 718 days had a total of eight litters. Age of animals and litter size are given in Table 6. In all the eight litters of the animals which recovered fertility

TABLE 5

RECUPERATION OF FERTILITY AFTER REMOVAL OF PELLETS FOLLOWING 394 DAYS OF STEROID-INDUCED STERILITY

\begin{tabular}{|c|c|c|c|c|c|c|}
\hline $\begin{array}{c}\text { Animal } \\
\text { No. }\end{array}$ & $\begin{array}{l}\text { Age at } \\
\text { first } \\
\text { implant } \\
\text { (days) }\end{array}$ & $\begin{array}{c}\text { Age } \\
\text { at removal } \\
\text { of pellets } \\
\text { (days) }\end{array}$ & $\begin{array}{l}\text { No. } \\
\text { litters after } \\
\text { removal of } \\
\text { pellet }\end{array}$ & $\begin{array}{c}\text { First litter } \\
\text { after removal } \\
\text { of pellet } \\
\text { (days) }\end{array}$ & $\begin{array}{l}\text { Survival } \\
\text { after removal } \\
\text { of pellet } \\
\text { (days) }\end{array}$ & $\begin{array}{c}\text { Age } \\
\text { at } \\
\text { death } \\
\text { (days) }\end{array}$ \\
\hline $\begin{array}{l}1 \\
2 \\
3 \\
4 \\
5 \\
6 \\
7\end{array}$ & $\begin{array}{r}101 \\
90 \\
96 \\
90 \\
109 \\
89 \\
96\end{array}$ & $\begin{array}{l}496 \\
485 \\
491 \\
485 \\
504 \\
484 \\
491\end{array}$ & $\begin{array}{l}0 \\
0 \\
0 \\
0 \\
3 \\
3 \\
2\end{array}$ & $\begin{array}{l}\overline{-} \\
\overline{-} \\
\overline{25} \\
34 \\
70\end{array}$ & $\begin{array}{r}21 \\
36 \\
36 \\
47 \\
112 \\
227 \\
227\end{array}$ & $\begin{array}{l}517 \\
521 \\
527 \\
532 \\
616 \\
711 \\
718\end{array}$ \\
\hline
\end{tabular}

Subcutaneous implantation of pellets containing $40 \%$ of 19 -nor-progesterone. Implantation renewed 220 days after the first one. Weight of pellets: 26 to $28 \mathrm{mg}$, or 10 to $11 \mathrm{mg}$ of 19-nor-progesterone. Absorption per day during the last 175 days: 16 (13 to 19) $\mu \mathrm{g}$.

TABLE 6

FERTILITY AFTER REMOVAL OF PELLETS IN ANIMALS WITH STEROID-INDUCED STERILITY OF 394 DAYS

\begin{tabular}{c|c|c|c|c|c|c}
\hline \multirow{2}{*}{\begin{tabular}{c|c|c|c|} 
Animal \\
No.
\end{tabular}} & \multicolumn{2}{|c|}{ First litter } & \multicolumn{2}{c|}{ Second litter } & \multicolumn{2}{|c|}{ Third litter } \\
\cline { 2 - 7 } & $\begin{array}{c}\text { Age } \\
(\text { days })\end{array}$ & $\begin{array}{c}\text { Size of } \\
\text { litter }\end{array}$ & $\begin{array}{c}\text { Age } \\
(\text { days })\end{array}$ & $\begin{array}{c}\text { Size of } \\
\text { litter }\end{array}$ & $\begin{array}{c}\text { Age } \\
(\text { days })\end{array}$ & $\begin{array}{c}\text { Size of } \\
\text { litter }\end{array}$ \\
\hline 5 & 529 & 2 & 559 & 4 & 611 & 4 \\
6 & 518 & 2 & 557 & 2 & 579 & 3 \\
7 & 561 & 3 & 661 & 4 & - & - \\
\hline
\end{tabular}

Details referring to Animals 5 to 7 of Table 5.

at an age of 17 to almost 19 months, the number of offspring per litter was between two and four, i.e. the same as in normal animals at this advanced age (Text-fig. 3). Indeed, in the four latest deliveries at 559 to 661 days, litter size was greater in the experimental animals than in normal animals at this age. But in view of the great variation of litter size at all ages these differences are of no significance. One is rather impressed by the coincidence as to production in the small comparable groups of normal and treated animals: the eight normal animals 501 to 558 days old produced eight litters with a total of twenty-four young (Table 1), and the three treated animals 518 to 561 days old produced five litters with a total of thirteen young (Table 6). 
There can scarcely be any doubt that aged animals, which are allowed to recover fertility after a sterility protracted for as long as 395 days, behaved as to litter frequency and litter size like normal aged animals.

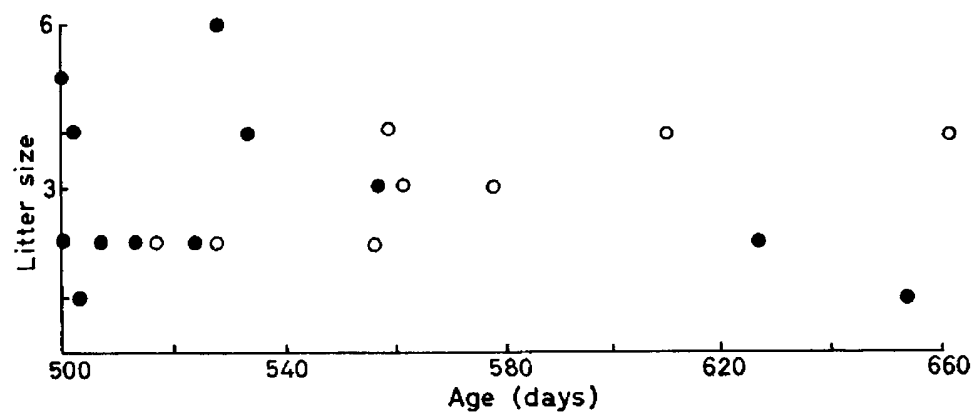

TEXT-FIG. 3. Comparative fertility in normal females (C), and in females which recovered fertility after the removal of the pellets of the steroid inducing sterility for 395 days $(0)$.

Fertility in the experimental group is quantitatively identical with that in the normal one. The last delivery took place in normal animals at an age of 655 days. In experimental animals there were still two litters at the age of 611 and 661 days.

Table 7

OVARIAN TUMOUR IN ANIMALS WITH PROTRAGTED STERILITY

\begin{tabular}{|c|c|c|c|c|c|c|}
\hline \multirow{2}{*}{$\begin{array}{c}\text { Table } \\
\text { and } \\
\text { (animal } \\
\text { No.) }\end{array}$} & \multirow{2}{*}{$\begin{array}{c}\text { Age } \\
\text { at } \\
\text { death } \\
\text { (days) }\end{array}$} & \multirow{2}{*}{$\begin{array}{l}\text { Duration } \\
\text { of } \\
\text { sterility } \\
\text { (days) }\end{array}$} & \multirow{2}{*}{$\begin{array}{l}\text { Condition } \\
\text { of animal }\end{array}$} & \multicolumn{2}{|c|}{$\begin{array}{l}\text { Condition of ovaries: } \\
\text { weight }(m g) \text { and structure }\end{array}$} & \multirow[t]{2}{*}{ Details } \\
\hline & & & & 1 & 2 & \\
\hline $2(9)$ & 693 & 402 & $\begin{array}{l}\text { Permanent } \\
\text { sterility }\end{array}$ & $\begin{array}{l}\text { GT } \\
1250\end{array}$ & $\begin{array}{l}\text { Very abundant } \\
\text { luteinization } \\
3 \mathrm{mg}\end{array}$ & Killed \\
\hline $5(4)$ & 532 & 395 & $\begin{array}{l}\text { Removal } \\
\text { of pellets }\end{array}$ & $\underset{140}{\mathrm{GT}, m}$ & $\begin{array}{l}\text { Very abundant } \\
\text { luteinization } \\
3 \mathrm{mg}\end{array}$ & Died \\
\hline $5(6)$ & 711 & 395 & $\begin{array}{l}\text { Removal } \\
\text { of pellets }\end{array}$ & $\begin{array}{r}\text { GT } \\
34\end{array}$ & $\begin{array}{l}\text { Abundant } \\
\text { Iuteinization } \\
3 \mathrm{mg}\end{array}$ & $\begin{array}{l}\text { Died; three litters; } \\
\text { last litter } 132 \text { days } \\
\text { before death }\end{array}$ \\
\hline $5(7)$ & 718 & 395 & $\begin{array}{l}\text { Removal } \\
\text { of pellets }\end{array}$ & $\underset{4}{\text { Small GT, }} m$ & $\begin{array}{l}\text { Abundant } \\
\text { luteinization } \\
4 \mathrm{mg}\end{array}$ & $\begin{array}{l}\text { Killed; two litters; } \\
\text { last litter } 57 \text { days } \\
\text { before death }\end{array}$ \\
\hline
\end{tabular}

$\mathrm{GT}=$ granulosa cell tumour; $m=$ mixed tumour, i.e. abundant luteinization also present.

\section{Ovarian tumours induced by 19-nor-progesterone}

In animals maintained sterile by 19-nor-progesterone, ovarian tumours were discovered, unexpectedly, at necropsy. * A short description of this finding has already been given (Lipschutz, Iglesias \& Salinas, 1962). The present paper deals only with aspects related to the problems of survival and procreation in animals with tumours.

Granulosa cell tumours were present in Animal 9 of Table 2 and Animals 4,

* We have just come across the important review of Dodds (1961). The author of the review was already fully aware of the relevant question of the dangers the use of 19-nor-steroids as contraceptive agents for long periods might imply (Dodds, p. X). 
6 and 7 of Table 5, i.e. in four out of eighteen animals. The ovaries reached a weight greatly in excess of the normal, which is rarely more than 3 to $4 \mathrm{mg}$. In all the four cases the granulosa cell tumour was unilateral. In the second ovary of these four animals and so also in the ovaries of the other fourteen treated animals, there was, as in normal aged females of our strain, abundant luteinization of the stroma (Lipschutz, 1960), but luteinization was much more pronounced in the treated animals than in normal aged animals (Lipschutz et al., 1962).

Graafian follicles (seven) were present only in Animal 5, the granulosa cell tumour occupying but a very small part of the ovary. In the remaining three animals there were no Graafian follicles in the ovary with the granulosa cell tumour. But Graafian follicles were present in the second luteinized ovary of all the four animals. Corpora lutea (seven) were present only in the second ovary of Animal 5.

No granulosa cell tumours were found in the normal females of Tables 1 and 3. Neither were they found in a second series of twenty-three normal animals not otherwise considered in the present paper. But both granulosa cell tumours and a high degree of luteinization were again found in a second series of animals maintained sterile with 19-nor-progesterone for as long as 375 to 511 days. The incidence both of granulosa cell tumours and of abundant luteinization of the stroma was the same as in the present series of treated animals.

We do not yet know for how long 19-nor-progesterone must be given to elicit ovarian tumours. In any case there is the fact that five litters were born in two animals with granulosa cell tumours after 395 days of 19-nor-progesterone. The first two of these litters were born 34 and 70 days after the removal of the steroid pellet; the delay was not greater than in animals without tumours (see Tables 5 and 6; also Lipschutz \& Iglesias, 1961 a, b). The last litters were born 132 and 57 days before the death of the mothers, which were 579 and 661 days old (Table 7). Even with normal animals this is a very rare event (see Table 1 and Text-fig. 3).

Thus there is seemingly complete evidence that recovery of fertility after a steroid-induced sterility of 395 days was not interfered with by tumours in those animals in which granulosa cell tumours were found at necropsy (Table 7), i.e. where tumours were present already before the reproductive life-span was finished, or were to develop afterwards.

\section{DISGUSSION}

The period of 13 months during which 19-nor-progesterone was administered, corresponds to about two-thirds of the life-span or to almost the whole reproductive life of our mice. The progestational steroid acts most probably on the hypophysis and through its intermediation on the ovary (summaries: Lipschutz, 1958; Lipschutz \& Iglesias, 1961b). One would suppose that the protracted treatment implies a tremendous effect on both the hypophysis and the ovary. However, this effect is most probably due not to a quantitative but only a chronological condition: the quantities of progesterone necessary for protracted inhibition of the luteinizing action of the hypophysis in earlier experiments of 
ours were not greater than those normally present in the blood during the luteal phase of the ovarian cycle (see Table 5 in Lipschutz \& Iglesias, 1961b; based on Rowlands \& Short, 1959 and Short, 1960; and R. V. Short, personal communication, 1961).

In our experiments the life-span of the treated animals was as long as that of normal animals. After the removal of the sterilizing steroid, fertility was recovered to the same degree as in normal aged females. As to fertility the female emerges from protracted sterility as an aged one! Thus the assumption can be made that under certain experimental conditions when the discontinuous, or rhythmic, interference of a gestagen is replaced by its continuous interference, both the ovary and the pituitary are held in check but without suffering any change in either their functional abilities or disabilities due to age. In other words a steroid-induced sterility lasting almost the whole reproductive life-span does not produce any change in the gerontological status of the ovary or hypophysis. There remains, as in Hunter's time, the immediate and unavoidable question about the gerontological factor, or factors, responsible for the decline both of litter frequency and of litter size. Our results, we must confess, do not contribute to solving this old question; rather do they emphasize its continued importance.

The decline of fertility in the aged female is not due to a diminution or exhaustion of oocytes in the ovary. Both in aged rats (Shelton, 1959) and mice (Jones \& Krohn, 1961a) the number of ova is the same in females which served as breeders and in those kept virgin. Similarly, our results make it very probable that the decline of fertility with advanced age does not depend on the decline in the number of oocytes; when the sterilizing pellets were removed and fertility was recovered, reproduction was resumed at the level of normal aged females although the use of the anti-ovulatory steroid must in the meantime have ensured maximum sparing of oocytes.

Much experimental work has also been done on the problem of an extraovarian age factor upon which follicular development and ripening might depend. Foetal or infantile ovaries grafted into spayed mature animals enter into premature follicular ripening and endocrine activity (Foà, 1901; Athias, 1916, 1922; Long \& Evans, 1922; Lipschutz \& Voss, 1925a). On the other hand, when the ovary of an adult female is grafted into an infantile animal follicular ripening and endocrine activity starts belatedly (Lipschutz, 1925b, 1926). There is thus the experimentally established fact that in rats and guinea-pigs follicular ripening at puberty depends not on the condition reached at this age by the ovary, but on an extra-ovarian factor coming into play at this age.

It was in those times only natural to assume that the extra-ovarian age factor is located in the pituitary. But subsequent findings were rather conflicting. Evidence was produced that sexual maturity is induced in immature mice by the administration of pituitary from sexually immature rats and even from a litter mate of the recipient (Smith \& Engle, 1927, p. 176). The gonadotrophic activity of the pituitary of infantile female rats of only 12 to $36 \mathrm{~g}$ when injected into young rats of 25 to $30 \mathrm{~g}$, is greatly superior to that of the pituitary of adult females (Lipschutz, 1933). Even the foetal pituitary contains gonadotrophins (Hellbaum, 1935; cited by Jones \& Ball, 1962, pp. 378-381). But all this does not allow us to presume that there is, in the foetus or infantile female, secretion 
of quantities of gonadotrophins sufficient to elicit follicular growth (Jones \& Ball (1962), p. 379).

Also the law of numerical follicular constancy can be overthrown experimentally by the administration of pituitary hormones to adult rats (Selye, 1947). But here again, is this result sufficient to explain the whole sequence of events as summarized by the above law?

Thus it would seem that so far it is not possible to declare the hypophyseal gonadotrophic hormones as the true or sole age factors of the ovary, be it at puberty or in maturity. The same seems to apply also when dealing with the problem of old age. This has been evidenced by experimental work with the pituitary of aged animals. The pituitary of an aged rat (Smith \& Engle, 1927, p. 178), or of an aged dog (Lipschutz \& Kallas, 1929), when injected into young mice, causes the same ovarian or uterine changes as the pituitary of a young animal does. On the other hand, attention has more recently been attracted to the fact that high titres of gonadotrophins are found in the blood and urine of post-menopausal women (Loraine, 1958; cited by Jones \& Ball, 1962, p. 381). The assumption that the aged ovary is unable to respond to pituitary hormones seems at first sight unavoidable. But so far there is no experimental knowledge about intrinsic qualities of the aged ovary which would speak in favour of such an unresponsiveness. Recently there has been the very relevant experimental statement that in new-born mice certain specific patterns of development of the oocytes which vary according to the strain, are independent of the maternal environment (Jones \& Krohn, 1962); they are genetically determined. Could the supposed unresponsiveness of the aged ovary be due to a genetically determined condition of the oocytes or to that of periovular cellular elements in the senescent ovary?

Our own results with the behaviour of animals which, after a protracted steroid-induced sterility, recover no more than the fertility of old animals of the same age which have already accomplished as much as $98 \%$ of their reproductive task-these striking results may at first sight centre our attention on the ovary itself as the carrier of the fundamental gerontological factor in reproduction. But our results offer no new knowledge which would allow us to locate this gerontological factor in the ovary, or in the hypophysis, or elsewhere in the body. It is the same with other recent knowledge of relevant facts. The decrease of litter size in ageing mice is due to the increase of regressing implantations in the uterus (Finn, 1962). However, and here again, the conclusion is reached that these results perforce leave open the question 'as to whether the failure of the implanted embryos to develop is due to structural changes in the uterus, changes in the endocrine environment or lethal factors in the eggs' (Finn, 1962, p. 500).

\section{AGKNOWLEDGMENTS}

This study was aided by a grant from the Population Council, New York, N.Y. Special thanks are due to Professor Warren O. Nelson, Medical Director, for the interest taken in our collaboration.

Cordial thanks for a generous supply of 19-nor-progesterone are due to Dr Alexander Zaffaroni, President of Syntex, Mexico. 


\section{REFERENCES}

ARA, H. (1920) On the cause of hypertrophy of the surviving ovary after semi-spaying (albino rat) and on the number of ova in it. Amer. F. Anat. 28, 59.

Asolel, S. A. (1924) Some effects of unilateral ovariotomy in rabbits. Brit. F. exp. Biol. $1,473$.

Athias, M. (1916) Etudes histologique d'ovaries greffés sur des cobayes mâtes châtrés. C.R. Soc. Biol., Paris, 79, 553.

Atrias, M. (1922) Etudes histologiques sur la greffé ovarienne, p. 79. Libro en honor de D. Santiago Ramon y Cajal.

Bigcers, J. D., Finn, C. A. \& McLaren, A. (1962a) Long-term reproductive performance of female mice. I. Effect of removing one ovary. 7. Reprod. Fertil. 3, 303.

Biggers, J. D., Finn, C. A., Mclaren, A. \& Woolf, B. (1962b) Long-term reproductive performance of female mice. II. Variation of litter size with parity. F. Reprod. Fertil. 3, 313.

Brambell, F. W. R. (1956) Ovarian changes. Marshall's Physiology of Reproduction, Vol. 1, p. 397. 3rd edn. Ed. A. S. Parkes. Longmans Green, London.

Bruce, H. M. (1959) Preliminary note on the effects of noroethisterone on mating behaviour and fertility in the mouse. Stud. Fertil. 10, 158.

Carmichael, E. S. \& Marshall, F. H. A. (1908) On the occurrence of compensatory hypertrophy in the ovary. 7 . Physiol. 36, 431.

Donos, C. (1961) Rime and reason in endocrinology. Proc. Soc. Endocrinol. J. Endocrin. 23, I-XI.

FinN, G. A. (1962) Embryonic death in aged mice. Nature, Lond. 194, 499.

FoÀ, C. (1901) Sur la greffé des ovaires. Arch. ital. Biol. 35, 364.

GreENWALd G. S. (1961) Quantitative study of follicular development in the ovary of the intact or unilaterally ovariectomized hamster. F. Reprod. Fertil. 2, 351.

Greenwald, G. S. (1962) Temporal relationship between unilateral ovariectomy and the ovulatory response of the remaining ovary. Endocrinology, 71, 664

HAMmond, J. (1925) Reproduction in the rabbit. Oliver \& Boyd, Edinburgh and London.

Hammond, J. (1952) Fertility. Marshall's Physiology of Reproduction, Vol. 2, p. 648. 3rd edn. Ed. A. S. Parkes. Longmans Green, London.

HaRTMan, C. G. (1925) Observations on the functional compensatory hypertrophy of the opossum ovary. Amer. F. Anat. 35, 1.

HunTER, J. (1787) An experiment to determine the effect of extirpating one ovarium upon the number of young produced. Philos. Trans. 77, 233.

Jones, E. C. \& KROHN, P. L. (1960a) The effect of unilateral ovariectomy on the reproductive life-span of mice. 7. Endocrin. 20, 129.

Jones, E. C. \& KRoHN, P. L. (1960b) Orthotopic ovarian transplantation in mice. F. Endocrin. 20, 135.

Jones, E. C. \& KRoHN, P. L. (1961a) The relationships between age, numbers of oocytes and fertility in virgin and multiparous mice. F. Endocrin. 21, 469.

Jones, E. C. \& KroHn, P. L. (1961b) The effect of hypophysectomy on age changes in the ovaries of mice. F. Endocrin. 21, 497.

JONES, E. G. \& KROHN, P. L. (1962) Effect of the maternal environment on strain-specific differences in the ovaries of new-born mice. Nature, Lond. 195, 1064.

Jones, I. C. \& Ball, J. N. (1962) Ovarian-pituitary relationships. The Ovary, Vol. 1, chap. 7, p. 361. Ed. S. Zuckerman. Academic Press, New York and London.

Lipschutz, A. (1925a) Dynamics of ovarian hypertrophy under experimental conditions. Brit. F. exp. Biol. 2, 331 .

Lipschutz, A. (1925b) Influence de l'age du porteur sur la fonction endocrine de la greffé ovarienne. C.R. Soc. Biol., Paris, 93, 1066.

Lipschutz, A. (1926) Der Einfluss des Alters des Wirtstieres auf des Zustandekomen des weiblichen hormonalen Effekts. Pflüg. Arch. ges. Physiol. 211, 745.

Lipschutz, A. (1927) On some fundamental laws of ovarian dynamics. Biol. Rev., Cambr. 21, 497.

Lipschutz, A. (1928) New developments in ovarian dynamics and the law of follicular constancy. Brit. F. exp. Biol. 5, 283.

Lipschutz, A. (1933) Über den Luteinisierungskoeffizienten der Hypophyse. Endokrinologie, Leipzig, 13, 90 [(1933) C.R. Soc. Biol., Paris, 112, 1145].

Lipschutz, A. (1958) Progesterone and its derivatives in the physiology and pharmacology of the hypophysial gonadotrophic function. Joseph Charvat ad Annum Sexagesimum, p. 113. (Statni Zdravotnicke Nakladatelstvi, Praga, 1958-Summary.)

LipschuTZ, A. (1960) Ovarian tumours and other tumoral responses induced by subtotal castration ("ovarian fragmentation") in mice. Acta Un. int. Cancr. 16, 149.

Lipschutz, A. \& ADAmberg, A. (1925) Nouvelles expériences sur la loi de la constance folliculaire. C.R. Soc. Biol., Paris, 93, 1464. 
Lipschutz, A., Adamberg, L., Tirsso, M. \& Veshniakov, S. (1926) Das Gesetz der konstanten Follikelzahl. Pfüg. Arch. ges. Physiol. 211, 682.

Lipschutz, A. \& Iglesias, R. (1961a) Recovery of fertility after protracted steroid-induced sterility in mice. Nature, Lond. 190, 174.

Lipschutz, A. \& Iglesias, R. (1961b) Esterilidad experimental prolongada en ratones y recuperación de la fertilidad. Acta physiol. lat.-amer. 11, 210.

Lipschutz, A., Iglesias, R. \& Salinas, S. (1962) Ovarian tumours induced by a sterilizing steroid. Nature, Lond. 196, 946.

Lipschutz, A. \& Kallas, H. (1929) Nouvelles observations sur les hormones hypophysaires et la loi de la puberté. C.R. Soc. Biol., Paris, 100, 30.

Lipschutz, A. \& Voss, H. E. (1924) Dynamique de l'hypertrophie ovarienne. C.R. Soc. Biol., Paris, 90, 199.

Lipschutz, A. \& Voss, H. E. (1925a) Experimenteller Hermaphroditismus und der Antagonismus der Geschlechtsdrüsen III. Pfï̈g. Arch. ges. Physiol. 207, 583.

Lipschutz, A. \& Voss, H. E. (1925b) Further developments on the dynamics of ovarian hypertrophy. Brit. F. exp. Biol. 3, 35.

Lipschutz, A., Wagner, Ch. \& TAMm, R. (1922) Sur l'hypertrophie des fragments ovariens dans la castration partielle. C.R. Soc. Biol., Paris, 86, 240.

Lipschutz, A., Wagner, C., TAMm, R. \& Bormann, F. (1922) Further experimental investigations on the hypertrophy of the sexual glands. Proc. roy. Soc. B, 94, 83.

Long, J. A. \& Evans, H. M. (1922) The oestrous cycle in the rat. Mem. Univ. Calif. 6. See p. 99.

Mande, A. M., Zugkerman, S. \& Patterson, H. D. (1952) The number of oocytes in ovarian fragments after compensatory hypertrophy. 7. Endocrin. 8, 347.

Mühlвock, O. (1957) The use of inbred strains of animals in experimental gerontology. Proc. Ciba Found. Coll. on Ageing, 3, 115.

Rowlands, I. W. \& Short, R. V. (1959) The progesterone content of the guinea-pig corpus luteum during the reproductive cycle and after hysterectomy. 7. Endocrin. 19, 81.

Selye, H. (1947) Textbook of endocrinology, pp. 339, 381 and 383. University of Montreal.

Shelton, M. (1959) A comparison of the population of oocytes in nulliparous and multiparous senile laboratory rats. F. Endocrin. 18, 451 .

Short, R. V. (1960) Blood progesterone levels in relation to parturition. 7. Reprod. Fertil. 1, $61,347$.

SLONAKER, J. R. (1927) Semi-ovariectomy compensatory hypertrophy of the remaining ovary and migration of the ova in the albino rat. Amer. 7. Physiol. 81, 620.

Smith, P. S. \& ENGLe, E. T. (1927) Experimental evidence regarding the role of the anterior pituitary in the development and regulation of the genital system. Amer. J. Anat. 40, 159.

Thung, P. J., Boot, L. M. \& Müнlвоск, O. (1956) Senile changes in the oestrous cycle and in ovarian structure in some inbred strains of mice. Acta endocr. 23, 8.

Zuckerman, S. (1962) The Ovary, Vol. 1. Academic Press, New York and London. 